\title{
IMPACTS OF TRADITIONAL MARKET REVITALIZATION ON THE TRADERS' CAPITAL EXPENDITURES IN SITUBONDO
}

\author{
Hasan Muchtar Fauzi, S.Sos.M.Si; Ahmad Yusuf Firdaus \\ hasanmuchtar.fauzi77@yahoo.com; fyrdhaus@gmail.com
}

\begin{abstract}
The impact of traditional market revitalization has an effect on the expenses and business capital of traders. Traditional markets are the economic fulcrum of the community, but traditional market conditions are synonymous with slums, dirty, smelly, irregular, muddy and so on. To survive the onslaught of modern markets there needs to be a revitalization of traditional markets, the emphasis is on the physical aspects of the market. so the hope of traders is that consumers interested in shopping in the market and the welfare of traders can increase, therefore researchers are interested in exploring the impact of market revitalization on traders in Situbondo Regency. The formulation of the problem is how the traditional market impacts on the expenses and capital of the merchant business, this type of research is (field research), is research conducted in the field by observing a phenomenon that is natural, while collecting data using observation, interviews and documentation. This study uses descriptive analysis method with a qualitative approach. The results show that the problems arising from revitalization are (1) the costs incurred by traders are very large, because they have to bear the costs of moving to a temporary place before occupying a revitalized market. (2) temporary relocation sites are very narrow and slum so that they have difficulty arranging their merchandise which has an impact on consumers' interest in shopping to decrease. (3) new buildings do not meet the expectations of traders, many traders complain starting from the size of the place that is too small and the design of buildings that are not in accordance with the products sold by certain traders (4) traders must renovate the kiosks provided by the market manager with the products they sell (5) due to the large amount of costs incurred by merchants ranging from temporarily moving to occupying new kiosks, the capital for their merchandise is reduced which results in incomplete merchandise.
\end{abstract}

Keywords: Revitalization Impact, Merchant Expenditures, merchandise capital.

\section{Introduction}

Traditional markets are markets managed by the government, local government, private sector, state-owned enterprises and regionally-owned enterprises including cooperation with the private sector with business places in the form of kiosks, kiosks, tents and managed by small, medium, community-based or cooperative traders. small scale businesses, small capital, and with the process of buying and selling merchandise through bargaining. While modern stores are shops with selfservice systems, selling several types of goods in retail in the form of mini markets, super markets, department stores, hypermarkets or wholesalers in the form of shipping. (Perpres No.122/2007).

Since the 1990s the spread of supermarkets has spread throughout all corners of the city, competing supermarkets with hypermarkets has led to small scale super markets, namely mini markets that can also compete with supermarkets because they offer the convenience of shopping that attracts consumers and almost the same pattern as supermarkets. Among them are Alfamart and Indomart who have mastered the 
market segments to the remote villages with the target of all levels of community elements. So that it narrows the space for traditional markets. (Kartika; 2014).

The phenomenon of the development of modern mini markets in almost all cities has an effect on economic development and has a significant impact on consumer purchasing power. Strategic location determination is a goal for the community to choose to shop in the modern market and leave the traditional market. (Anggraini: 2013). The price of cheap goods is definitely considered a distinct advantage for consumers. This trend will have an impact on traditional markets. responding to this kind of shift in consumer behavior can be observed since the 1980s, the middle and upper class economic communities are able to shop at the super market, and local traditional markets begin to lose prestige (Reardon at all 2003; Collectt \& Wallace; 2006).

The existence of a traditional market as a nation's asset which is a people's economic base and a social security institution as a culture of institutional resilience can only exist amid the grandeur of modern retail if it gets the attention of the government in the form of policies to protect traditional markets, both traders, consumers and the public other markets. Market development must consider factors that benefit the market community and must be managed professionally with good management. (Kalman at. All 2016).

Therefore the government must take a policy to revitalize the traditional market so that its existence continues to exist in the midst of society. The purpose of revitalization is to develop traditional markets and local communities into favorable conditions, which are not limited to certain limits. Although stakeholders get financial benefits, development must have many benefits for the community. The government and the developer must pay attention to the interests of the local community who are the target of development (Dwinovanto \& Rudito; 2014)

The number of traditional markets revitalized through the trade ministry coadministration fund in 2016 was 133 markets in districts and cities, the realization of the market revitalization missed the original 168 plans in 166 municipal districts. A total of 32 markets were launched (carry over) in 2017 and also planned to be built as many as 272 market units. The development target of 5,000 markets in five years or 1,000 per year. Aside from the trade ministry assistance fund, market revitalization is also sourced from the Ministry of Finance's Special Allocation Fund (DAK). The market revitalization program is proven to be able to increase trade transactions two to three times compared to before (Estu; 2017).

During this time the traditional market revitalization process is only based on observing market conditions and requests from traders, without prior studies that can provide accurate information that might be a consideration and fulfill the requirements for revitalization (Kursini \& Kismanto; 2011). Until most of the traditional market traders are not satisfied with revitalization, both from the management aspect and from the aspect of the building (Kursini; 2010). 
The government has implemented a special program for traditional market development, namely the development of markets in each sub-district. The implementation of the program was made so that regional trade activities in the districts were not only concentrated in the city center but also in the periphery which had a high degree of accessibility, and with the development of local trade activities each sub-district would help achieve equitable economic activities in all sub-districts.

Revitalization of buildings is very important to be done by the government and regional governments so that traditional markets can compete with modern markets. In revitalizing traditional markets.

Research Questions

a. Does traditional market revitalization have an impact on costs incurred by traders?

b. Does the traditional market revitalization have an impact on the business capital of the traders?

Research Objectives

a. To find out the impact of revitalization on costs incurred by traders.

b. To find out the impact of revitalization on business capital of traders.

Research Advantages

a. For traders, it can be a reference for improvement in improving the quality of goods arrangement and the quality of products marketed.

b. For the government and the market manager, it can be a reference to improve better market revitalization in accordance with mutual expectations.

c. For researchers, they can study more deeply about the issue of revitalization.

\section{Research Methods}

This study uses a qualitative descriptive type of research, by conducting indepth interviews and field observations, the focus of this research leads to the impact of traditional market revitalization on the costs expended by traders and merchant business capital after being revitalized. Secondary data is data obtained from literature studies and other supporting data, the technique of determining informants is done by purposive and snowboll, meaning the determination starts from small scope to large. Data collection is done by direct observation

of space, examining the situation and conditions of traditional markets by conducting in-depth interviews, and documentation using supporting literature. According to Milles and Huberman the presentation of the four stages of data analysis can be explained as follows; 


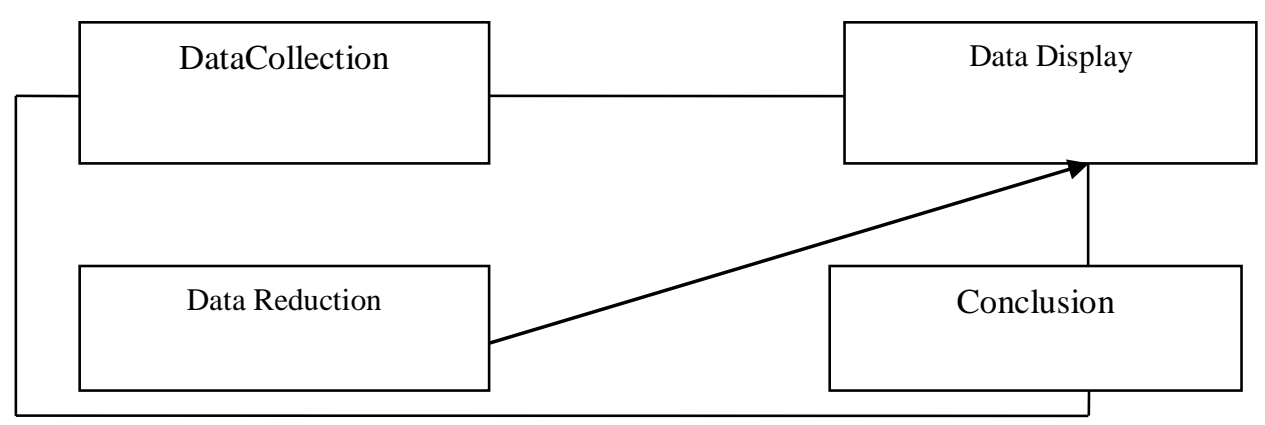

(Milles dan Huberman 1984)

Informants here were taken from several warriors who experienced traditional market revitalization in Situbondo. Among them are in the table below;

\begin{tabular}{|c|c|c|}
\hline No & Markets & $\begin{array}{c}\text { Number of } \\
\text { Informants }\end{array}$ \\
\hline 1 & Pasar Sumberkolak & 3 \\
\hline 2 & Pasar Ardirejo & 2 \\
\hline 3 & Pasar Panarukan & 3 \\
\hline 4 & Pasar Asembagus & 2 \\
\hline 5 & Pasar Panji & 2 \\
\hline 6 & Jumlah & 12 \\
\hline
\end{tabular}

The research framework model is as follows;

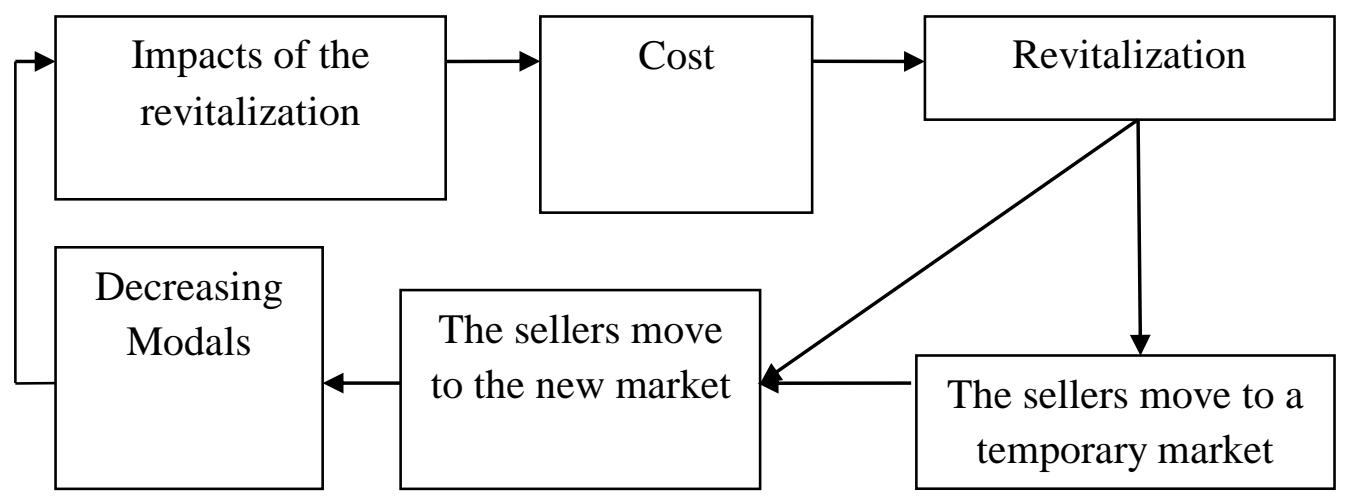

\section{Finding and Discussion}

Revitalization of buildings is very important to be carried out by the government and regional governments so that traditional markets can compete with the modern market, in addition to the strict rules for the modern market so that the distribution can be controlled. In revitalizing traditional markets the government places more emphasis on market infrastructure, so that market buildings are feasible in accordance with the expectations of traders and consumers to shop comfortably. Cases that occurred in Situbondo district, the panarukan market, the resource market and several other traditional markets there were several problems related to the 
development of market infrastructure, so traders had to renovate the kiosks provided to suit the needs of the traders.

Starting from the initial stages of development planning, market managers ask traders to immediately move to temporary places that have been provided, with a minimum period of 7 days to a maximum of 15 days, because revitalization will be done soon. Factors of unpreparedness are a problem for traders, because the time specified is too short and seems rushed. Besides that, traders must improve to move to a temporary place which is located far from the market and also nearby as located behind the market to be built.

Problems that cause traders' anxiety begin to be felt because the temporary place used is not feasible, even narrow and traders feel uncomfortable selling. Customers or consumers do not recognize their new place. Certainly the impact on the decline of consumers shopping in traditional markets which results in traders' income dropped dramatically.

Moving to a temporary place requires a relatively large cost to build a new stall or kiosk, this is a problem for traders because some of their capital is used up to build stalls and kiosks. If the market development has been completed, the traders will be reallocated the revitalized place. Usually development carried out by the government takes approximately one year in the process of completion.

Traiders are not satisfied with the new buildings provided by the government, because they are not in line with the expectations of those who are already accustomed to the relatively wide conditions of the place being replaced with smaller ones. Before being revitalized, the traders occupy old kiosks, measuring 3x6 meters on average, even wider for certain merchandise such as glassware with kiosks measuring 6x12 M2. However, after the revitalization of the existing designs did not match the expectations of the traders, initially they were promised a minimum size of $3 \times 3$ meters in fact only $2.5 \times 2.5$ meters was obtained. The narrow kiosk factor forced traders to renovate their rooms to fit their merchandise. To renovate a room, of course, the costs incurred by traders are not small, so that since starting to move temporarily to occupy a new kiosk, the funds spent are very large which are drained from their merchandise capital.

Many traders who protest the above conditions even lead to demonstrations of traders against the government such as in the Panarukan market, which does not want to move to a place that has been revitalized and wants to remain in a temporary place. Likewise in the market, compote sources are many traders who protest because the stalls they get are too small and not according to the initial plan. Their hope is that at least the kiosks obtained are the same as those they occupy before being revitalized, because traders have used the relatively large space for decades and replaced with smaller ones. Similar cases occur in other markets such as the Ardirejo market and even the newly built Panji market has collapsed and resulted in fatalities among some traders.

Revitalization that is not taken seriously by the government will not change the traditional market situation between before and after the revitalization of its building 
forms, there is no significant increase in consumers, and even tends to decrease, and in the end traditional markets will not compete with modern markets.

\section{Conclusions}

a. The time given to traders to move temporarily is too short so that the preparations made by traders to build kiosks and stalls seem to be in a hurry, and coupled with a location that is less strategic and narrow causes irregular and slums-like arrangement. Even zoning that is far from the revitalized market location reduces the interest of consumers shopping for traditional markets because customers do not know the location of the merchants they subscribe to.

$\mathrm{b}$. Moving to a temporary place requires a lot of money, because the place provided is only in the form of vacant land, the traders have to rebuild a new stall or kiosk. This forced the traders to spend the usual costs for business capital instead of making temporary kiosks / stalls, which eventually would be dismantled after moving to a revitalized place. Likewise, to move to a place that has been revitalized requires additional costs, because the manager only provides empty stalls or kiosks which of course need to be modified according to merchandise or products sold.

c. The kiosk provided is not in accordance with the original plan that has been socialized by the developer. Traders are not satisfied with new buildings, because they are too small. Before being revitalized, traders usually occupy kiosks with an average size of $3 \times 6 \mathrm{~m} 2$, even $6 \times 12 \mathrm{~m} 2$, adjusting to their merchandise. But after being revitalized, the kiosks provided are only $2.5 \mathrm{~m} 2$ in size, which makes it difficult for traders to develop their wares.

\section{Suggestions}

a. Giving time to the traders, the market manager should consider the duration of the time is longer with the provisions that have been previously set. Because the traders must prepare their move and revamp their merchandise. This has an impact on the psychological condition of those who seem to be in a hurry pursued by the moving deadline.

b. In determining the location of the move, the market manager should consider a strategic place, with regular arrangement and the distance is not far from the revitalized market. The government must provide temporary kiosks / stalls which are prepared for market revitalization, so that traders do not spend too much on transfer funds which results in reduced merchandise capital.

c. In revitalizing the market, the management should consider and want to hear the input of traders, because they have a variety of merchandise. 


\section{REFERENCES}

2007. No.112. Penataan dan Pembinaan Pasar Tradisional Pusat Perbelanjaan dan

Toko Modern. Jakarta: Peraturan Presiden Republik Indonesia.

Dwinovanto R. Dimas Putra \& Bambang Rudito.2014. Planning Community Development Program of Limbangan Traditional Market Revitalization with Social Mapping. Procedia - Social and Behavioral Sciences 169 ( 2015 ) 143 - 150. 2014 The Authors. Published by Elsevier Ltd.

Edukasi News. 2013. IKAPPI Jawa Timur, Tinggal Beberapa Hari Serah Terima Pasar Panji Ambruk.https://edukasionlinestyle.blogspot.com/2013/11/ikappi-jawatimur-tinggal-beberapa-hari.html.

Estu Suryowati. 2017. Berapa pasar tradisional yang sudah dibenahi pemerintah pada 2016?.Downloaded.December.2017.https://ekonomi.kompas.com/read/201 7/01/05/074400126/beberapa.pasar.tradisionl

Jawa Pos.Radar Banyuwangi;2017. Pedagang Pasar Panarukan Pindah Massal. https://radarbanyuwangi.jawapos.com/read/2017/08/12/7085/pedagan g-pasar-panarukan-pindah-masal

Kartika D. Sri Susilowati,. 2014. The Impacts Of Modern Market To Traditional Traders (A Case In Malang City - Indonesia) .International Journal of Technical Research and Applications e-ISSN: 2320-8163, www.ijtra.com Volume-2, Special Issue 8, PP. 38-44

Kalman, Kajagi, Aminuddin Ilmar, Ahmadi Miru, Juajir Sumardi.2016. Traditional Market Presence in Retail Trade Crush. Journal of Law, Policy and Globalization ISSN 2224-3240 (Paper) ISSN 2224-3259 (Online) Vol.49, 2016 www.iiste.org

Kusrini, Dwi Endah, “Traders Satisfaction of Market Traditional Analysis”, Surabaya, PD Pasar Surya Final Report, 2010.

Kusrini, D. E, "Market Potensial Research of Gayungsari Market," Final report, PD.Pasar Surya, Surabaya, 2010.

Kusrini, Dwi Endah \& Arie Kismanto. 2011. Market Potential Research For The Revitalization Of Traditional Markets. Proceedings of The $1^{\text {st }}$ International Conference on Information Systems For Business Competitiveness (ICISBC) 2011

Miles, M.B, dan Huberman, M. 1984. Qualitative Data Analisys A Sourcebook of New Method. Baverly I Hills London New Delhi: Sage Publication. 
Mudradjad Kuncoro. 2008. Strategi Pengembangan Pasar Modern dan Tradisional.(http://www.kadinindonesia.or.id/enm/images/dokumen/KADIN-107-2998-18072008.pdf)

Prabowo, Edhy. Sulis Madi. Safri, Pius Lustrilanang. Existence and Revitalization of Traditional Markets against Modern Markets Development. J. Basic. Appl. Sci. Res., 7(1)1-16, 2017. Journal of Basic and Applied Scientific Research. ISSN 2090-4304. www.textroad.com

Majalah Gempur.2017. Kondisi Pasar Program Revitalisasi Di Situbondo Memprihatinkan. http://www.majalah-gempur.com/2017/04/kondisi-pasar-programrevitalisasi-di.html

Reardon, T. C., Timmer, P., Barrett, C. B., \& Berdegué, J. (2003). The rise of supermarkets in Africa, Asia, and Latin America. American Journal of Agricultural Economics, 85(5), 1140-1146. 